\title{
Attitude of Local Dwellers towards Ecotourism in the Okomu National Park, Edo State Nigeria
}

\section{Oghenetejiri Digun-Aweto', Ogbanero Pipy Fawole², Ibukun Augustine Ayodele ${ }^{1}$}

e-mail: tejiri.aweto@gmail.com, opfawole@yahoo.com, profibukunayodele@yahoo.com

'Department of Wildlife and Ecotourism Management, Faculty of Agriculture and Forestry,

University of Ibadan, Nigeria

${ }^{2}$ Department of Agricultural Extension and Rural Development, Faculty of Agriculture and Forestry, University of Ibadan, Nigeria

Digun-Aweto, O., Fawole, P. O., \& Ayodele, I. A. (2015). Attitude of Local Dwellers towards Ecotourism in the Okomu National Park, Edo State Nigeria. Czech Journal of Tourism, 4(2), 103-115. DOI: 10.1515/cjot-2015-0007.

\begin{abstract}
Ensuring local community support for national parks is viewed as a paramount ingredient for conservation and sustainability. This is advocated for the park to meet its conservation goals. The Okomu National Park (ONP), Edo State, Nigeria, is one of such protected areas of lush green rain forest requiring conservation.

This study examined the local inhabitants' attitudes view on ecotourism towards the national park and its importance to natural resource conservation in ONP. The park is home to the endangered white throated monkey and the forest elephant.

Data were collected on the basis of questionnaires, distributed among eight communities, which have a direct relationship with the park. A total of 338 questionnaires were distributed in eight communities around the park. The results of the survey revealed positive attitudes towards ecotourism in the area of the conservation of wildlife (69\%). In addition, $71 \%$ of respondents thought that ecotourism helped in saving their forests.

A positive relationship between benefits derived, educational level, religion, family size and being a native of the area and attitudes were established, suggesting that these significant factors play an important role in influencing local support for conservation. Among the major limitations the local inhabitants listed their exclusion as copartners in the management of the park and the prohibitive laws that deprive the locals of gathering non-timber forest products, which negatively affects their livelihood. ONP conservationists should work at improving their relationship with the host communities, and include them in management activities. Only then can development and conservation goals be achieved.
\end{abstract}

\section{Keywords}

Attitude, Okomu National Park, Ecotourism

JEL classification: Q26, Q57, Z30 


\section{Introduction}

The assessment of the attitudes of the locals is very important in sustaining the conservation in the protected areas where endemic species exist. The rise in anthropogenic activities usually affects the conservation goals of the protected areas. These interests may not be in favour of the locals based on their attitudes and perceptions of the park programmes of the Okomu National Park. The major negative attitudes arise from a lack of access to non-timber forest products and few or no economic benefits. Adams and Infield (2003) reported that areas designated to protect species and invariably their habitats are the primary focus of the conservation strategies. However, the local communities perceive the loss of access to these lands as a limitation of their source of livelihood which is dependent on natural resources and agricultural development of these protected areas.

The Okomu National Park is the smallest of Nigeria's seven national parks, covering a total area of $181 \mathrm{~km}^{2}$. It was formerly the Okomu Wildlife Sanctuary, created in 1985 to protect the white-throated monkey (Cercopithecus eruthrogaster) and forest elephants (Loxodonta africana cyclotis). It is a forest block carved out of the $1082 \mathrm{~km}^{2}$ Okomu Forest Reserve in the Ovia South-West Local Government Area of Edo state in Nigeria gazette in 1935.

The national park is about $60 \mathrm{~km}$ north-west of Benin city. It lies between latitudes $6^{0} 15^{\prime}$ and $6^{0} 25 \mathrm{~N}$ and longitudes $5^{\circ} 9^{\prime}$ and $5^{023} \mathrm{E}$. In 1999 it was transformed into a national park. It holds a small fragment of the rich forest that once covered the region and it is the last habitat for many endangered species (Ajayi, 2002). This makes it a diversity hotspot.

The main objective of this research is to determine the attitudes of the host communities towards ecotourism.

\section{Theoretical basis}

Research studies in this field confirm the benefits and importance of local people's participation (Kiss, 2004; Pollnac \& Pomeroy, 2005). In addition, there have been a few studies (Stem et al., 2003; De los Angeles Somarriba-Chang \& Gunnarsdotter, 2012) that identify the factors that influence this participation in development projects. The studies have identified a range of factors or reasons why local communities do or do not participate in the development projects, including the ecotourism projects. Powerful project members have a potential impact on the participation of people in rural development projects. Njoh (2002) identified that powerful members will influence the selection/ participation of those who are involved. Adebayo (1985) also observed that local leaders had a significant role in influencing the participation in community based projects in Nigeria. This is clearly supported by Oakley (1991) who commented that a lack of local leadership skills when implementing the project resulted in non-participation due to the households not being confident and, therefore not wanting to be involved in the activities. This is reflected in the study by Tewari and Khanna (2005), who conducted 


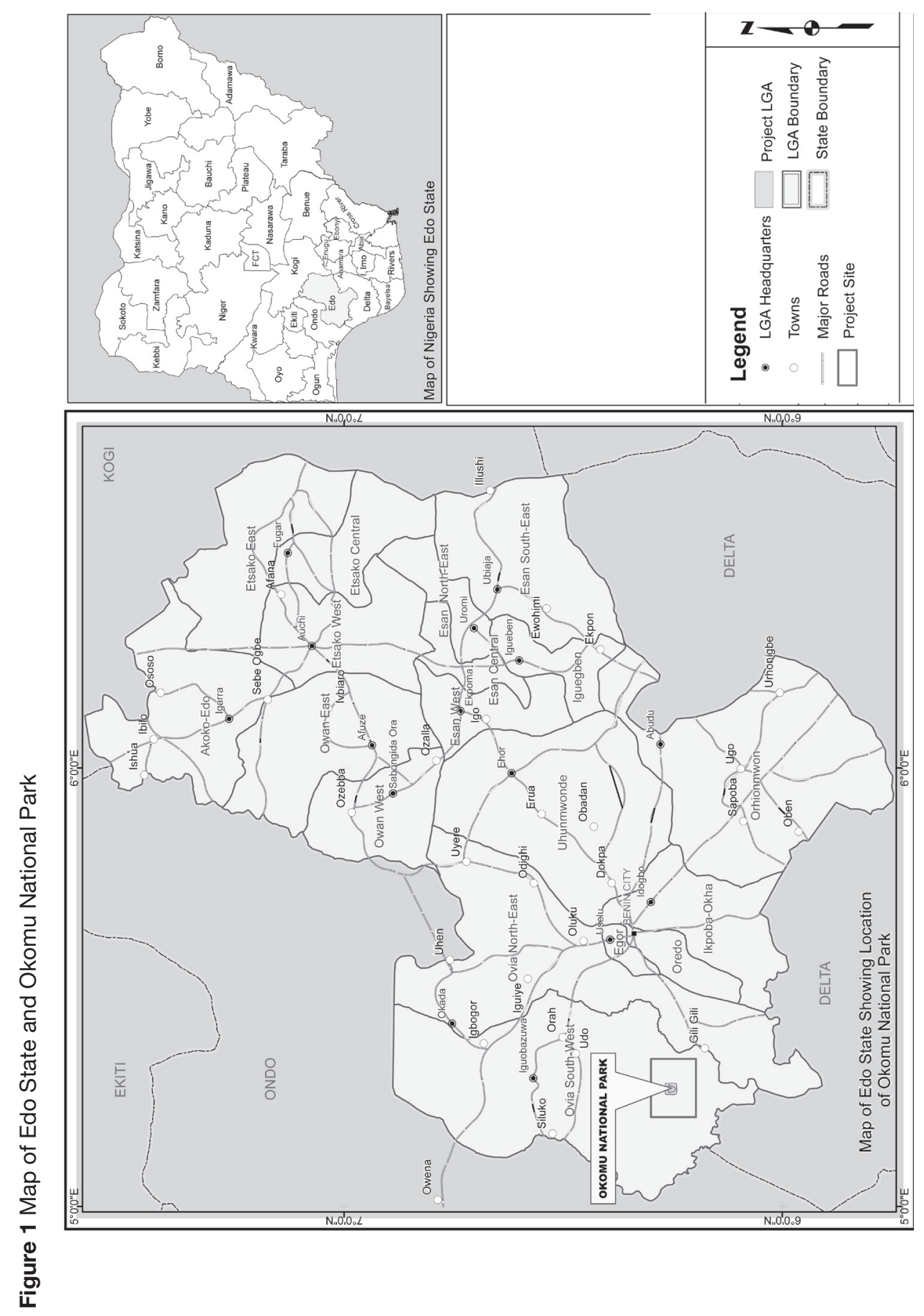

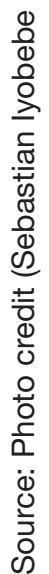


research on the success of farmers' participation in the irrigation management in Gujarat. They discovered that effective local leadership was one reason why people were motivated to participate in the project. The reason was their trust in their local leaders. They found out that good leaders were able to get on well with their community, to speak for them, have honest discussions with them, and to be able to spend time or make extra efforts to solve problems in their communities. Wilson, Fesenmaier, Fesenmaier, and Van Es (2001) claimed that it was important to recognize that local leaders were able to make a difference in the amount of community participation and increase the chance of a tourism project being successful. The level of education and literacy also affected people's participation in the community development projects (Glendinning, Mahapatra, \& Mitchell, 2001). These authors found out that the more educated people were more aware of the benefits that could be gained from their participation than the illiterate people. This is supported by Lise (2000) who conducted a study on household participation in the forest management and conservation in India. He discovered that the literate villagers in three states including Bihar, Haryana, and Uttar Pradesh were more likely to be involved in the forestry activities compared to the illiterate. Likewise, Abdulai and CroleRees (2001) studied farm and community development in Southern Mali. They found out that the educated households were more likely to participate in the non-farm sector than the less educated. Thus, to increase the local people's participation, the people's capability, especially in literacy, must be considered in the community development projects (Briedenhann \& Wickens, 2004).

\section{Methodology}

A reconnaissance survey was carried out in ONP to discover the area, and to acquire the first-hand information on the locals and ecotourism concerns in the park. A set of pretest survey questionnaires was administered to evaluate the reliability of the instrument using the split half method. The primary data were collected through structured questionnaires. A multistage random sampling technique was used in selecting communities around the park, based on their distance from the park which gave a total of 3,374 households from the selected communities. Ten percent of the total households were then randomly selected from the communities. Thereafter a structured questionnaire was distributed to 350 households. The data were collected from both primary and secondary sources. The primary data sources were obtained from the household survey through the structured questionnaires, consisting of both open and close-ended questions, based on a set of questions in relation to the study objectives. The secondary information was obtained through an extensive literature review of various documents and park records. A total of 338 questionnaires were collected for the analysis. The questionnaire included questions about respondents' general attitudes towards ecotourism and conservation. This research attempted to identify the relationships between residents' socio-economic and demographic attributes and their attitudes toward ecotourism, which is: To examine residents' attitudes toward tourism in the Okomu National Park. The questionnaire con- 
sisted of 20 statements and a 20 item five point likert-type response format based on the following scale: $(1=$ strongly disagree; $2=$ disagree; $3=$ neutral; $4=$ agree; $5=$ strongly agree). The data were analysed by using SPSS version 20 .

\section{Results}

\section{Personal characteristics of the respondents}

Table 1 below shows that $58.98 \%$ of the respondents were married, $36.7 \%$ were singles, while $4.4 \%$ were divorced. About $60 \%$ of the community members were farmers and they usually use family labour to work on the farm. This is the reason why the married percentage is high.

Over $60 \%$ of the respondents of the host communities are males, while $34.0 \%$ of them are females. Asmamaw and Verma (2013) also reported a similar result, stating that $85 \%$ of the respondents in a similar study carried out in the Bale Mountains National Park in Ethiopia were males and $74 \%$ of them were also farmers.

About $40 \%$ of the respondents were between $31-40$ years, $24.0 \%$ of the respondents were between 21-30 years, $21.9 \%$ were between ages $41-50,9.8 \%$ of the respondents were below 20 years, while $0.6 \%$ of them were 50 years and above. Fiagbomeh and BurgerArndt (2013) in their research on the Kakum conservation area in Ghana reported that $56.4 \%$ of the members of the host communities' ages were in the range of 30-50 years. Shibia (2010) also stated that $51 \%$ of the respondents were between the ages of 25-40 years, representing the most productive age group targeted for development.

The results show that $22.2 \%$ of the respondents had no formal education, $9.2 \%$ of them had a primary school certificate, $44.4 \%$ of them had a secondary school certificate, while $24.3 \%$ of them had a tertiary school certificate. Akosim et al. (2010) also reported that $60 \%$ of the members of the host communities received secondary school education. Asmamaw and Verma (2013) stated that $52 \%$ of the respondents in the Bale Mountains National park in Ethiopia had at least primary education.

The table also reveals that $60.1 \%$ of the respondents were farmers, $15.7 \%$ of them were traders, and $14.8 \%$ of them were students, while $9.5 \%$ had other occupations. Asmamaw and Verma (2013) also illustrated that the dominant occupation of border communities in national parks was agriculturally based, accounting for $74 \%$ of the population. The findings of Shibia (2010) also support this result, revealing that $35.8 \%$ of the locals depend on crop farming, forty-eight of the respondents (25.7\%) were agro-pastoralist while $18 \%$ were pastoralists. Furthermore, Wahab and Adewunmi (2013) reported that 93\% of the male members of the host communities in the Kainji Lake National Park were engaged in agricultural activities.

The results also reveal that $40.8 \%$ of the respondents were between 3-5 family members, $27.2 \%$ of the respondents had only two family members, $14.2 \%$ of them had a family size ranging from $6-8$ members, while $17.8 \%$ of them had above 8 family members. Due to the fact that the predominant occupation is farming as indicated in Table 1, the large family size is a means of cheap family labour. 
Table 1 Personal characteristic of the respondents

\begin{tabular}{|c|c|c|}
\hline Personal Characteristics & Frequency & Percentage \\
\hline \multicolumn{3}{|l|}{ Age } \\
\hline Below 20 years & 33 & 9.8 \\
\hline $21-30$ years & 81 & 24 \\
\hline $31-40$ years & 138 & 40.8 \\
\hline $41-50$ years & 74 & 21.9 \\
\hline Above 50 years & 12 & 0.6 \\
\hline Total & 338 & 100 \\
\hline \multicolumn{3}{|l|}{ Gender } \\
\hline Male & 223 & 66 \\
\hline Female & 115 & 34 \\
\hline Total & 338 & 100 \\
\hline \multicolumn{3}{|l|}{ Marital status } \\
\hline Single & 124 & 36.7 \\
\hline Married & 199 & 58.9 \\
\hline Divorced & 15 & 4.4 \\
\hline Total & 338 & 100 \\
\hline \multicolumn{3}{|l|}{ Educational level } \\
\hline No formal education & 75 & 22.2 \\
\hline Primary education & 31 & 9.2 \\
\hline Secondary education & 150 & 44.4 \\
\hline Tertiary education & 82 & 24.3 \\
\hline Total & 338 & 100 \\
\hline \multicolumn{3}{|l|}{ Occupation } \\
\hline Farmer & 203 & 60.1 \\
\hline Trader & 53 & 15.7 \\
\hline Student & 50 & 14.8 \\
\hline Others & 32 & 9.5 \\
\hline Total & 338 & 100 \\
\hline \multicolumn{3}{|l|}{ Family size } \\
\hline $2-4$ & 92 & 27.2 \\
\hline $5-7$ & 138 & 40.8 \\
\hline 8 & 48 & 14.2 \\
\hline 8 and above & 60 & 17.8 \\
\hline Total & 338 & 100 \\
\hline
\end{tabular}

Source: field survey (2014) 


\section{Attitude of the host communities towards ecotourism}

Table 2 shows an overview of the attitude of the host communities towards ecotourism with an overall mean of $(\bar{x}=3.72)$. The results also indicate that the majority of the host community members have not visited the park. In addition, the results show that there is a high awareness level of the community that there is a national park in their environment with a mean of $(\bar{x}=4.24)$. These results are supported by Akosim et al. (2010) who reported that the attitude towards ecotourism was due to the consciousness of the existence of the park by the host communities (96.8\%), the reason for establishing the park $(94.3 \%)$ and knowledge of the laws, protecting the park $(91.6 \%)$, in spite of the low literacy level. This attitude is based on the anticipation that things might change and that they will likely benefit from the park more in future.

The community also believes that ecotourism has helped in protecting the environment $(\bar{x}=3.62)$. The results indicated that the community was always neglected when it came to ecotourism decision making with a mean of $(\bar{x}=3.55)$. This has made the members of the host community have a negative attitude towards ecotourism and the park because neglecting them makes them feel unimportant and not relevant. Dimitrakopoulos et al. (2010) noted that when local communities outside the boundaries of the protected areas were not included in the conservation planning process, conflicts between conservation goals and community wants and needs arose. These conflicts resulted from the constraints imposed by the protected area management on land use and natural resource extraction. Restrictions regarding the access to the protected area, agricultural activities, timber extraction, hunting or other such activities, are just some of the most frequent sources of the protected area-local community conflicts (Brandon et al., 2005). The results further indicated that the community attitudes towards preservation of game had a mean of 4.22. This could be a reason why poaching is high. Most often, conservation puts pressure on the local people who depend on these resources. In addition, Ozturk et al. (2010) argue that damaging effects of local rural population pressure are exacerbated by the fact that most of these people are generally the poorest section of the rural population and the common belief is that natural forest resources are free for the benefit of everyone. In conclusion, it can be said that host communities' attitude towards ecotourism is above average, the majority of the attitudinal statements are below the overall mean score, which has a value of $(\bar{x}=3.72)$. 
Table 2 Frequency distribution showing attitudes of the host communities towards ecotourism

\begin{tabular}{|c|c|c|c|c|c|c|}
\hline Attitudes & SD & $\mathrm{D}$ & $\mathrm{U}$ & A & SA & $\begin{array}{l}\text { Mean } \\
\text { score }\end{array}$ \\
\hline $\begin{array}{l}\text { Do you know that there is a national park } \\
\text { in your environment? }\end{array}$ & $10.70 \%$ & $1.20 \%$ & $0.30 \%$ & $29.00 \%$ & $58.80 \%$ & 4.24 \\
\hline $\begin{array}{l}\text { I hunt game anytime; I feel like eating bush } \\
\text { meat. }\end{array}$ & $52.40 \%$ & $32.50 \%$ & $5.60 \%$ & $3.80 \%$ & $5.50 \%$ & 4.22 \\
\hline Conservation education is a waste of time. & $53.00 \%$ & $29.30 \%$ & $5.00 \%$ & $7.10 \%$ & $5.60 \%$ & 4.17 \\
\hline $\begin{array}{l}\text { Game (animals) are meant to be food for } \\
\text { the community, so why should I preserve } \\
\text { them? }\end{array}$ & $55.60 \%$ & $21.60 \%$ & $7.70 \%$ & $8.60 \%$ & $6.50 \%$ & 4.11 \\
\hline $\begin{array}{l}\text { Ecotourism is one of the ways of exposing } \\
\text { the community to danger. }\end{array}$ & $50.60 \%$ & $25.70 \%$ & $9.80 \%$ & $6.50 \%$ & $7.40 \%$ & 4.06 \\
\hline $\begin{array}{l}\text { I will never welcome anything has to do } \\
\text { with conservation }\end{array}$ & $49.10 \%$ & $29.60 \%$ & $5.00 \%$ & $8.30 \%$ & $8.00 \%$ & 4.04 \\
\hline $\begin{array}{l}\text { Ecotourism is a means of depriving the } \\
\text { people of their natural environment. }\end{array}$ & $49.40 \%$ & $29.60 \%$ & $4.70 \%$ & $7.10 \%$ & $9.20 \%$ & 4.03 \\
\hline $\begin{array}{l}\text { I dislike ecotourism because tourists make } \\
\text { things more expensive. }\end{array}$ & $40.80 \%$ & $37.30 \%$ & $9.20 \%$ & $6.80 \%$ & $5.90 \%$ & 4.00 \\
\hline $\begin{array}{l}\text { There is nothing to gain from the } \\
\text { conservation. }\end{array}$ & $45.90 \%$ & $30.80 \%$ & $6.80 \%$ & $10.40 \%$ & $6.20 \%$ & 4.00 \\
\hline Conservation has aided denial of rights. & $47.30 \%$ & $26.00 \%$ & $7.10 \%$ & $10.80 \%$ & $8.60 \%$ & 3.93 \\
\hline $\begin{array}{l}\text { Conservation discourages traditional } \\
\text { medicine. }\end{array}$ & $47.00 \%$ & $26.60 \%$ & $7.10 \%$ & $10.40 \%$ & $8.90 \%$ & 3.93 \\
\hline $\begin{array}{l}\text { Conservation is another form of } \\
\text { colonization. }\end{array}$ & $46.40 \%$ & $27.40 \%$ & $4.40 \%$ & $10.10 \%$ & $11.50 \%$ & 3.87 \\
\hline $\begin{array}{l}\text { I do not care about the ecosystem (forests } \\
\text { and animals). }\end{array}$ & $39.10 \%$ & $35.20 \%$ & $4.40 \%$ & $13.00 \%$ & $8.30 \%$ & 3.84 \\
\hline $\begin{array}{l}\text { Conservation of wildlife and flora is } \\
\text { unfamiliar to our culture. }\end{array}$ & $44.10 \%$ & $21.90 \%$ & $6.20 \%$ & $18.60 \%$ & $9.20 \%$ & 3.73 \\
\hline Conservation reduces sources of income. & $41.70 \%$ & $26.30 \%$ & $7.10 \%$ & $13.30 \%$ & $11.50 \%$ & 3.73 \\
\hline $\begin{array}{l}\text { Ecotourism leads to the spread of } \\
\text { diseases. }\end{array}$ & $41.40 \%$ & $24.60 \%$ & $9.20 \%$ & $15.40 \%$ & $9.50 \%$ & 3.73 \\
\hline $\begin{array}{l}\text { Conservation limits the use of traditional } \\
\text { herbs. }\end{array}$ & $38.80 \%$ & $31.70 \%$ & $7.70 \%$ & $6.80 \%$ & $15.10 \%$ & 3.72 \\
\hline $\begin{array}{l}\text { Tourists create competition among the } \\
\text { community members. }\end{array}$ & $32.00 \%$ & $33.40 \%$ & $13.00 \%$ & $10.70 \%$ & $10.90 \%$ & 3.65 \\
\hline $\begin{array}{l}\text { Conservation reduces the consumption of } \\
\text { animal protein. }\end{array}$ & $39.20 \%$ & $26.00 \%$ & $6.40 \%$ & $16.60 \%$ & $11.50 \%$ & 3.65 \\
\hline $\begin{array}{l}\text { Ecotourism helps in protecting our wild } \\
\text { life. }\end{array}$ & $19.80 \%$ & $3.00 \%$ & $6.20 \%$ & $37.30 \%$ & $33.70 \%$ & 3.62 \\
\hline
\end{tabular}




\begin{tabular}{|c|c|c|c|c|c|c|}
\hline Attitudes & SD & $\mathrm{D}$ & $U$ & A & SA & $\begin{array}{l}\text { Mean } \\
\text { score }\end{array}$ \\
\hline Ecotourism helps in saving our forest. & $17.80 \%$ & $7.70 \%$ & $5.90 \%$ & $34.30 \%$ & $34.30 \%$ & 3.60 \\
\hline $\begin{array}{l}\text { Ecotourism is a means of exploiting the } \\
\text { community members. }\end{array}$ & $37.30 \%$ & $24.00 \%$ & $11.80 \%$ & $14.50 \%$ & $12.40 \%$ & 3.59 \\
\hline $\begin{array}{l}\text { The community is always neglected when } \\
\text { it comes to ecotourism decision making. }\end{array}$ & $38.20 \%$ & $14.20 \%$ & $10.90 \%$ & $17.80 \%$ & $18.90 \%$ & 3.53 \\
\hline $\begin{array}{l}\text { Ecotourism is a way of increasing the } \\
\text { household income. }\end{array}$ & $41.40 \%$ & $15.70 \%$ & $9.80 \%$ & $20.40 \%$ & $12.70 \%$ & 3.53 \\
\hline Strangers are welcome in our community. & $20.10 \%$ & $12.10 \%$ & $4.10 \%$ & $31.10 \%$ & $32.40 \%$ & 3.44 \\
\hline I have made a couple of visits to the park. & $20.70 \%$ & $17.50 \%$ & $19.50 \%$ & $21.30 \%$ & $21.00 \%$ & 3.04 \\
\hline $\begin{array}{l}\text { Ecotourism has greatly developed the } \\
\text { community. }\end{array}$ & $36.10 \%$ & $4.70 \%$ & $11.50 \%$ & $21.90 \%$ & $25.70 \%$ & 2.96 \\
\hline $\begin{array}{l}\text { Most people in my community have } \\
\text { a negative attitude towards ecotourism. }\end{array}$ & $38.10 \%$ & $21.90 \%$ & $10.10 \%$ & $20.10 \%$ & $9.80 \%$ & 2.41 \\
\hline
\end{tabular}

Source: Field survey (2014)

\section{Relationship between the host community attitudes, demographics and benefits}

The level of formal education associated with the respondents' age influenced the attitudes. The educated people may have more knowledge of the conservation related issues which could have resulted from a high level of interaction in learning and/or exposure to media. The community members who are unfavourable to the biodiversity conservation have a weak formal education level. This result supports the positive link between consciousness about the biodiversity conservation and education. The higher level of education also helps to understand the role of the park and the usefulness of the conservation of its biological diversity. Another important reason which explains a relatively high impact of education on people's positive perception of biodiversity is that those with a good level of education rarely engage in agriculture as their major source of livelihood. Not surprisingly, education has a powerful effect on attitudes towards conservation as explained by Tomićević et al. (2010). This finding reinforces the important role of education in the sustainable biodiversity conservation, which is in line with the findings of Shibia (2010). This study also found out that those who had gained benefits directly or indirectly had had a positive attitude towards conservation and ecotourism.

In addition, the occupation of the locals had a significant effect on their attitudes, majorly because most of the host community members are mostly engaged in agricultural related activities, or hunting, and these activities are directly related to natural resources. Their restriction for accessing the protected areas has brought about the negative attitude about ecotourism and conservation in a few locals. Furthermore, for the sake of posterity, the locals have developed a positive attitude towards conservation. Thus, the 
significant relationship between the conservation of natural resources and ecotourism. Even though they may not be given access to the protected areas, the locals still have a sense of ownership.

Table 3 Regression analysis showing a relationship between the attitude of the locals and the selected variables (demographic characteristics and benefits)

\begin{tabular}{|c|c|c|c|c|c|c|}
\hline \multirow{2}{*}{$\begin{array}{l}\text { Model } \\
1\end{array}$} & $\mathbf{R}$ & \multicolumn{2}{|c|}{ R Square } & \multicolumn{2}{|c|}{ Adjusted R Square } & $\begin{array}{c}\text { Std. Error } \\
\text { of the Estimate }\end{array}$ \\
\hline & $.676^{a}$ & & 457 & .442 & & 437 \\
\hline \multirow[t]{2}{*}{ Model } & & Sum of Squares & df & Mean Square & $\mathrm{F}$ & Sig. \\
\hline & Regression & 125292.863 & 9 & 13921.429 & 30.644 & $.000^{\mathrm{b}}$ \\
\hline \multirow[t]{2}{*}{1} & Residual & 149011.137 & 328 & 454.302 & & \\
\hline & Total & 274304.000 & 337 & & & \\
\hline \multirow{3}{*}{\multicolumn{2}{|c|}{ Model }} & \multicolumn{2}{|c|}{$\begin{array}{l}\text { Unstandardized } \\
\text { Coefficients }\end{array}$} & $\begin{array}{c}\text { Standardized } \\
\text { Coefficients }\end{array}$ & $\mathrm{T}$ & Sig. \\
\hline & & B & Std. Error & Beta & & \\
\hline & & -37.534 & 9.225 & & -4.069 & .000 \\
\hline & 23.821 & 2.409 & .411 & 9.890 & $.000^{\star}$ \\
\hline \multicolumn{2}{|c|}{ Native } & 3.283 & 2.344 & .064 & 1.401 & .162 \\
\hline \multicolumn{2}{|c|}{$\begin{array}{l}\text { Marital status } \\
\text { Sex }\end{array}$} & -3.023 & 2.373 & -.050 & -1.274 & .204 \\
\hline \multicolumn{2}{|l|}{ Age } & .651 & 1.373 & .023 & .474 & .636 \\
\hline \multicolumn{2}{|c|}{ Educational level } & -1.024 & .193 & -.230 & -5.307 & $.000^{*}$ \\
\hline \multicolumn{2}{|c|}{$\begin{array}{l}\text { Occupation } \\
\text { Religion }\end{array}$} & 3.547 & 1.257 & .128 & 2.821 & $.005^{\star}$ \\
\hline \multicolumn{2}{|c|}{ Family size } & 6.902 & 2.323 & .117 & 2.972 & $.003^{*}$ \\
\hline \multirow{2}{*}{\multicolumn{2}{|c|}{ Benefits of ecotourism }} & -2.121 & 1.211 & -.077 & -1.751 & .081 \\
\hline & & .754 & .061 & .521 & 12.307 & $.000^{*}$ \\
\hline
\end{tabular}

Source: field survey (2014)

\section{Discussion}

The results are in line with the findings of Abdullahi et al. (2007), who reported that the people living around the park were aware of the need to protect forests for the sake of posterity, which was one reason the attitudes towards ecotourism were well above average. The findings of this research also support the findings of Vodouhê et al. (2010), who stated that age and gender were significant predictors of positive attitudes towards ecotourism and biodiversity conservation. The first reason is that the rulers of the com- 
munities are the major beneficiaries and therefore the majority of the members of the community do not get any direct benefits.

Ecotourism has been tagged as the fastest growing sector in tourism (Coria \& Calfucura, 2012). In fact, it is able to create income sources to foster conservation and improve education thorough environmental education. The educational level is one variable that has an impact on people's attitudes towards ecotourism because the more knowledgeable they are about what ecotourism is trying to achieve, the more positive their attitude towards ecotourism is. Those who had unfavourable attitudes had weak or low levels of formal education. This finding supports the connection between consciousness of conservation and education as echoed by Tomićević et al. (2010). In this case study, the authors explained that those with good formal education level had better jobs in antipoaching and tourism sectors. A good level of education helps to understand the reason for setting up the park and the benefits of conservation

Another reason is that those with good formal education are not usually involved in agricultural jobs such as teaching or working in local or national governmental or other private sector organisations. They are not usually in contact with the park or staff of the park unlike those with the low level of education. This supports the fact that those with the low level of education are usually involved in agricultural related activities and usually have grievances against the park because of farming and hunting activities. For example, some farm land which some respondents use for agricultural activities belongs to the park and this has been a big issue. These findings support the paramount role that education plays in the sustainable biodiversity conservation

\section{Conclusions}

This study has shown patterns in local attitudes towards ecotourism and conservation. It is clear that there is a relationship between the attitudes and benefits from ecotourism even though they have not been transformed into financial gains and sustainable development yet as they would envisage although the locals have been employed by the park. The study has not revealed many negative attitudes because the park is still relatively young, patterns of attitudes, both of conservation and ecotourism, may change over time as ecotourism develops. The study broadly recommends that more conservation programmes should be implemented by the park and non-governmental organisations to improve the awareness of the benefits of conservation and hence, ecotourism. This will form a good foundation for partnerships between the host communities and the Okomu National Park. Further studies should focus on the ways through which ecotourism can help improve the livelihoods of the locals in the area

\section{Acknowledgements}

I would like to thank the staff of the Okomu National Park and Mr Oladipo Cornelius Ojo for their assistance during this research. Special thanks to Mr Matthew and Mr Folusho. 


\section{References}

Adams, W. M., \& Infield, M. (2003). Who is on the gorilla's payroll? Claims on tourist revenue from a Ugandan National Park. World development, 31(1), 177-190.

Abdulai, A., \& CroleRees, A. (2001). Determinants of income diversification amongst rural households in Southern Mali. Food policy, 26(4), 437-452.

Abdullahi, M. B., Sanusi, S. S., Abdul, S. D., \& Sawa, F. B. (2007). Perception of support zone communities towards the conservation of Yankari Game Reserve, Bauchi State, Nigeria. International Journal of Pure and Applied Sciences, 1(2), 49-57.

Adebayo, A. (1985). The implications of community leadership for rural development planning in Nigeria. Community Development Journal, 20 (1) 24-31. DOI: 10.1093/cdj/20.1.24

Ajayi, S. S. (2002). Multipurpose Forest Management for Bushmeat Production: a success story from West Africa. 1-18. Retrieved from Food and Agriculture Organization of the United Nations, Forestry Web site: http://www.fao.org/forestry/10258-0c60dbb6d55b4eb656bacabf3808aa4a3.pdf

Akosim, C., Bode, A. S., Kwaga, B. T., \& Dishan, E. E. (2010). Perceptions and Involvement of Neighboring Communities of Kainji Lake National Park towards the Parks Conservation Programmes. Journal of Research in Forestry, Wildlife and Environment, 2(1), 44-59.

Asmamaw, D., \& Verma, A. (2013). Local attitudes towards environmental conservation and ecotourism around Bale Mountains national park, Ethiopia. Scholarly Journal of Agricultural Science, 3(11), 506-514.

Brandon, K., Da Fonseca, G. A., Rylands, A. B., \& Da Silva, J. M. C. (2005). Special section: Brazilian conservation: challenges and opportunities. Conservation Biology, 19(3), 595-600. DOI: 10.1111/j.1523-1739.2005.00710.x

Briedenhann, J., \& Wickens, E. (2004). Tourism routes as a tool for the economic development of rural areas-vibrant hope or impossible dream? Tourism management, 25(1), 71-79.

Coria, J., \& Calfucura, E. (2012). Ecotourism and the development of indigenous communities: the good, the bad and the ugly. Ecological Economics, 73, 47-55

De los Angeles Somarriba-Chang, M., \& Gunnarsdotter, Y. (2012). Local community participation in ecotourism and conservation issues in two nature reserves in Nicaragua. Journal of Sustainable Tourism, 20(8), 1025-1043.

Dimitrakopoulos, P. G., Jones, N., Iosifides, T., Florokapi, I., Lasda, O., Paliouras, F., \& Evangelinos, K. I. (2010). Local attitudes on protected areas: Evidence from three Natura 2000 wetland sites in Greece. Journal of Environmental Management, 91(9), 1847-1854.

Glendinning, A., Mahapatra, A., \& Mitchell, C. P. (2001). Modes of communication and effectiveness of agroforestry extension in eastern India. Human ecology, 29(3), 283-305. DOI: 10.1023/A:1010954631611

Fiagbomeh, R., \& Burger-Arndt, R. (2010). Local community's perceptions and attitudes towards protected areas and ecotourism management. The case of Kakum Conservation Area, Ghana. A paper presented at the $2^{\text {nd }}$ world ecotourism conference Kuala Lumpur, Malaysia on the 8-1 $1^{\text {th }}$ July 2010 (pp. 3-9). Retrieved from http://www.discoverymice.com/WEC2010/world-ecotourismconference-2010-speakers.htm

Kiss, A. (2004). Is community-based ecotourism a good use of biodiversity conservation funds? Trends in Ecology and Evolution, 19(5), 232-237. 
Njoh, A. J. (2002). Barriers to community participation in development planning: lessons from the Mutengene (Cameroon) self help water project. Community Development Journal, 37(3), 233-248. DOI: $10.1093 / \mathrm{cdj} / 37.3 .233$

Lise, W. (2000). Factors influencing people's participation in forest management in India. Ecological economics, 34(3), 379-392. DOI: 10.1016/S0921-8009(00)00182-8

Oakley, P. at al. (1991). Projects with people: The practice of participation in rural development. Geneva, Switzerland: International Labour Office. 304 p.

Ozturk, A., Saglam, B., \& Barli, O. (2010). Attitudes and perceptions of rural people towards forest protection within the scope of participatory forest management: A case study from Artvin, Turkey. African Journal of Agricultural Research, 5(12), 1399-1411.

Pollnac, R. B., \& Pomeroy, R. S. (2005). Factors influencing the sustainability of integrated coastal management projects in the Philippines and Indonesia. Ocean $\mathcal{E}$ coastal management, 48(3), 233251. DOI: 10.1016/j.ocecoaman.2005.04.003

Shibia, M. G. (2010). Determinants of attitudes and perceptions on resource use and management of Marsabit National Reserve, Kenya. Journal of Human Ecology, 30(1), 55-62.

Stem, C. J., Lassoie, J. P., Lee, D. R., Deshler, D. D., \& Schelhas, J. W. (2003). Community participation in ecotourism benefits: The link to conservation practices and perspectives. Society $\mathcal{E}^{\circ}$ Natural Resources, 16(5), 387-413. DOI: 10.1080/08941920309177

Tomićević, J., Shannon, M. A., \& Milovanović, M. (2010). Socio-economic impacts on the attitudes towards conservation of natural resources: case study from Serbia. Forest Policy and Economics, 12(3), 157-162. DOI: 10.1016/j.forpol.2009.09.006

Tewari, D. D., \& Khanna, S. (2005). Building and energizing water institutions: A case study of irrigation management transfer in Gujarat. Journal of Environmental Systems, 31(3), 201-221. DOI: 10.2190/ES.31.3.a

Vodouhê, F. G., Coulibaly, O., Adégbidi, A., \& Sinsin, B. (2010). Community perception of biodiversity conservation within protected areas in Benin. Forest Policy and Economics, 12(7), 505-512. DOI: 10.1016/j.forpol.2010.06.008

Wahab, M. K. A, \& Adewumi, A. A. (2013). Assessment of Community Participation in Protected Area: A Case Study of Kainji Lake National Park, Nigeria. International Journal of Economics, Finance and Management, 2(1), 15-20.

Wilson, S., Fesenmaier, D., Fesenmaier, J., \& Van Es, J., (2001). Factors for success in rural tourism development. Journal of Travel Research, 40(2), 132-138. DOI: 10.1177/004728750104000203 